\title{
Detection of Bacterial Wilt Pathogen and Isolation of Its Bacteriophage from Banana in Lumajang Area, Indonesia
}

\author{
Hardian Susilo Addy, ${ }^{1,2}$ Norita Fatatik Azizi, ${ }^{1}$ and Paniman Ashna Mihardjo ${ }^{1}$ \\ ${ }^{1}$ Department of Plant Protection, Faculty of Agriculture, University of Jember, Jember 68121, Indonesia \\ ${ }^{2}$ Center for Development of Advanced Sciences and Technology, University of Jember, Jember 68121, Indonesia \\ Correspondence should be addressed to Hardian Susilo Addy; hsaddy.faperta@unej.ac.id
}

Received 14 October 2015; Accepted 6 March 2016

Academic Editor: Othmane Merah

Copyright (c) 2016 Hardian Susilo Addy et al. This is an open access article distributed under the Creative Commons Attribution License, which permits unrestricted use, distribution, and reproduction in any medium, provided the original work is properly cited.

\begin{abstract}
Bacterial wilt disease on banana is an important disease in Lumajang District and causes severe yield loss. Utilizing bacteriophage as natural enemy of pathogenic bacteria has been widely known as one of the control strategies. This research was aimed at determining the causing agent of bacterial wilt on banana isolated from Lumajang area, to obtain wide-host range bacteriophages against bacterial wilt pathogen and to know the basic characteristic of bacteriophages, particularly its nucleic acid type. Causative agent of bacterial wilt was isolated from symptomatic banana trees from seven districts in Lumajang area on determinative CPG plates followed by rapid detection by PCR technique using specific pair-primer. Bacteriophages were also isolated from soil of infected banana crop in Sukodono District. Morphological observation showed that all bacterial isolates have similar characteristic as common bacterial wilt pathogen, Ralstonia solanacearum. In addition, detection of FliC region in all isolates confirmed that all isolates were $R$. solanacearum according to the presence of $400 \mathrm{bp}$ of FliC DNA fragment. Moreover, two bacteriophages were obtained from this experiment ( $\phi$ RSSKD1 and $\phi$ RSSKD2), which were able to infect all nine R. solanacearum isolates. Nucleic acid analysis showed that the nucleic acid of bacteriophages was DNA (deoxyribonucleic acid).
\end{abstract}

\section{Introduction}

The most popular crop cultivated in East Java, Indonesia, is banana tree due to existence of about 33 of banana germplasm in this area [1]. The production of banana increases annually and is affected by environmental factors such as plant disease [2]. Bacterial wilt disease, caused by Ralstonia solanacearum, is one of the most important pathogens on banana plantation [3]. Nasir et al. [4] described that bacterial wilt on infected banana, caused by $R$. solanacearum, showed unique symptoms as yellowing on affected leaf, appearance of bacterial ooze, and rotting on infected-plant parts. In addition, bacterial colonies on cassaminoacid peptone glucose (CPG) agar medium are fluidal-white but become pink spot on white colony while growing on CPG agar medium containing triphenyle tetrazolium chloride (TZC) [5]. Elphinstone [6] reported that this bacterium causes yield loss about 80 to $100 \%$ in diseased banana crop. On the other hand, another bacterial wilt on banana has also been identified as banana Xanthomonas wilt disease caused by Xanthomonas vasicola pv. musacearum with similar morphological symptom as shown in bacterial wilt disease caused by $R$. solanacearum [7] .

$R$. solanacearum is soil borne pathogen, very diverse in its species, and belongs to group of Ralstonia-species complex. Due to its diversity in species and strain, suitable diagnostic procedure should be done to identify this pathogen accurately including molecular diagnostic such as polymerase chain reaction using specific primer [8]. In the other hand, diagnosis of pathogen is also possible by using bacteriophage due to its specificity to infect very narrow bacterial host within family, genus, or species [9].

Several management techniques have been tried to control bacterial wilt with less effectiveness such as the use of chemical pesticides, resistant plant, and culture technique methods [10]. In addition, Addy et al. [11] suggested a new method to control this pathogen by using bacteriophage. 
Fujiwara et al. [12] successfully utilized bacteriophage to control bacterial wilt on tomato. In citrus, Ahmad et al. [13] also demonstrated that utilization of XacF1 suppresses the development of citrus canker disease caused by X. citri. Moreover, utilization of bacteriophage to control pathogenicbacteria has been suggested as a tool in disease management strategy, called phage therapy [14], besides its utilization as detection tool for specific bacteria [15].

According to bacterial status, determination of pathogen should be accurately done efficiently and effectively. Moreover, according to benefit of utilization of bacteriophage, isolation of bacteriophage should be the first step in all procedures prior to exploring and use of bacteriophage [11]. Therefore, the present study was conducted to determine bacterial wilt pathogen isolates of banana in Lumajang, Indonesia, by PCR technique and to isolate virulent bacteriophage that is able to infect all isolates of bacterial wilt pathogen.

\section{Method}

2.1. Plant and Soil Sampling. Sampling was done in seven districts in Lumajang, Indonesia, such as Sukodono, Randu Agung, Kedung Jajang, Tempeh, Tekung, Yosowilangun, and Pasru Jambe (Figure 1). For isolation of bacteriophage, soil sample was taken from Sukodono District. A hundred grams of soil sample was collected from 10 to $30 \mathrm{~cm}$ deep using pipe $(3 \mathrm{~cm}$ in diameter) and was put into plastic bag. Sample was stored in $4^{\circ} \mathrm{C}$ until further use.

2.2. Isolation Bacterial Wilt Pathogen of Banana. Stem pieces of wilted banana plants were disinfected using 70\% alcohol solution and were placed in Petri dish under moist condition to spur the formation of bacterial ooze on the stem pieces surface. Bacterial ooze, which appeared on stem piece surface, was then streaked on the CPG medium containing $0.01 \%$ of TZC. After 48 hours of incubation at $28^{\circ} \mathrm{C}$, a fluidal colony with pink spot on white colony on the plate was selected as a putative $R$. solanacearum. The colony was soluble in $3 \%$ of $\mathrm{KOH}$ solution and was infiltrated into tobacco leaf as hypersensitive response test. The single colony of each isolate was regrown on CPG broth for 24 hours and subjected to DNA extraction and purification and PCR detection followed protocol of Sambrook et al. [16].

2.3. Detection by Polymerase Chain Reaction. To determine and confirm isolates as $R$. solanacearum, molecular method like PCR-based identification was done by using a FliC pairprimer which is specific to amplify the flagellin gene sequence in $R$. solanacearum [17]. The primer sequences for FliC$\mathrm{R}$ and FliC-L were (5'-GAACGCCAACGGTGCGAACT$3^{\prime}$ ) and ( $5^{\prime}$-GGCGGCCTTCAGGGAGGTC- $\left.3^{\prime}\right)$, respectively, and the expected PCR product size was $400 \mathrm{bp}$. Briefly, PCR condition was predenaturation at $94^{\circ} \mathrm{C}$ for 3 minutes, 35 cycles of denaturation at $94^{\circ} \mathrm{C}$ for 30 seconds, annealing at $63^{\circ} \mathrm{C}$ for $2 \mathrm{~min}$, and elongation at $72^{\circ} \mathrm{C}$ for $1 \mathrm{~min}$. Final extension was done at $72^{\circ} \mathrm{C}$ for $3 \mathrm{~min}$. PCR product was then visualized using UV Gel Documentation System (Major
Sciences) on $1 \%$ of agarose gel electrophoresis stained using GelGreen (Biotium).

2.4. Isolation Bacteriophage and Nucleic Acid. Bacteriophages were isolated from soil samples collected from Sukodono district according to the method described by Susianto et al. [18]. Isolated pure bacteriophages were stored in SM buffer at $4^{\circ} \mathrm{C}$ conditions until future use [11]. Phages nucleic acid was isolated and purified following Susianto et al. [18] and was used for characterization of nucleic acid by nuclease enzymes such as DNAse and RNAse as described below.

2.5. Host Range Assay of Bacteriophage. Host range assay was done in vitro to determine the lysing ability of each bacteriophage against $R$. solanacearum. The assay was done as spot test method as described by Susianto et al. [18]. Briefly, $400 \mu \mathrm{L}$ suspensions of $R$. solanacearum isolates (at $\mathrm{OD}_{600}$ of 1 with 24 -hour culture) were mixed with soft agar $(0.3 \%$ agarose) and poured onto CPG agar plates. Once soft agar solidified, a $2 \mu \mathrm{L}$ phage suspension (using a micropipette) was spot-inoculated on the surface of agar and allowed to dry at room temperature prior to incubation at $28^{\circ} \mathrm{C}$. Lysed areas on the spot inoculations were observed until 48 hours.

2.6. Characterization of Bacteriophage Nucleic Acid. Phages nucleic acid was characterized using DNAse and RNAse by incubating $1 \mu \mathrm{g} / \mu \mathrm{L}$ of nucleic acid in $20 \mu \mathrm{L}$ of reaction containing 1 unit of DNAse I or RNAse. All reactions (mixture of $\mathrm{ddH}_{2} \mathrm{O}$, nucleic acid, enzyme buffer, and enzyme) were incubated at $37^{\circ} \mathrm{C}$ for 2 hours prior to visualization on agarose gel electrophoresis.

\section{Results}

About $40 \%$ of districts in Lumajang have been chosen as location for sampling related to the occurrence of banana wilt symptom, such as districts of Yosowilangun, Randu Agung, Tempeh, Pasrujambe, Tekung, Sukodono, and Kedung Jajang. All of the banana trees showed similar symptoms such as wilting (Figure 2(a)) with yellowing on fruits (Figure 2(b)); brown and red spots were observed on symptomatic fruits (internal symptom) when sliced vertically and horizontally (Figures 2(c) and 2(d)). In addition, the banana's stem also showed similar brown and red lines along the stem (Figure 2(e)). Interestingly, brown-red liquid mass appeared after 48 hours while stem section (Figure 2(f)) was incubated under humid condition (Figure $2(\mathrm{~g})$ ). To confirm the causative pathogen of this disease, we isolated the agent using determination medium (CPG) containing $0.01 \%$ of triphenyl tetrazolium chloride (TZC). The result showed that white colonies, white with red spot, were grown on the media as bacterial colonies (Figures 3(a) and 3(b)).

About nine isolates were collected from 7 locations and different banana hosts such as variety of Raja (Musa textilia) and variety of Kepok (Musa acuminata balbisiana). All isolates were Gram-negative bacteria according to the $\mathrm{KOH}$ solubility test and showed similar reaction while the bacterial suspension was infiltrated onto the tobacco leaves 
TABLE 1: Bacterial isolates used in this study.

\begin{tabular}{|c|c|c|c|c|c|}
\hline No & Origin & Banana's variety $^{\mathrm{a}}$ & Isolate code & $\mathrm{KOH}$ solubility test & $\begin{array}{l}\text { Hypersensitive } \\
\text { response induced in } \\
\text { tobacco leaves }\end{array}$ \\
\hline \multirow{2}{*}{1} & \multirow{2}{*}{ Tempeh } & \multirow{2}{*}{ Kepok } & TP1 & + & + \\
\hline & & & TP2 & + & + \\
\hline \multirow{2}{*}{2} & \multirow{2}{*}{ Randu Agung } & \multirow{2}{*}{ Kepok } & RA1 & + & + \\
\hline & & & RA2 & + & + \\
\hline 3 & Pasru Jambe & Raja & PJ1 & + & + \\
\hline 4 & Kedung Jajang & Raja & $\mathrm{KJ} 2$ & + & + \\
\hline 5 & Yosowilangun & Kepok & Yoso & + & + \\
\hline 6 & Tekung & Raja & TKG & + & + \\
\hline 7 & Sukodono & Kepok & SKD & + & + \\
\hline
\end{tabular}

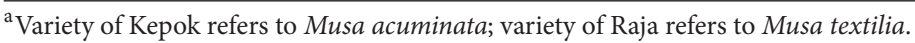

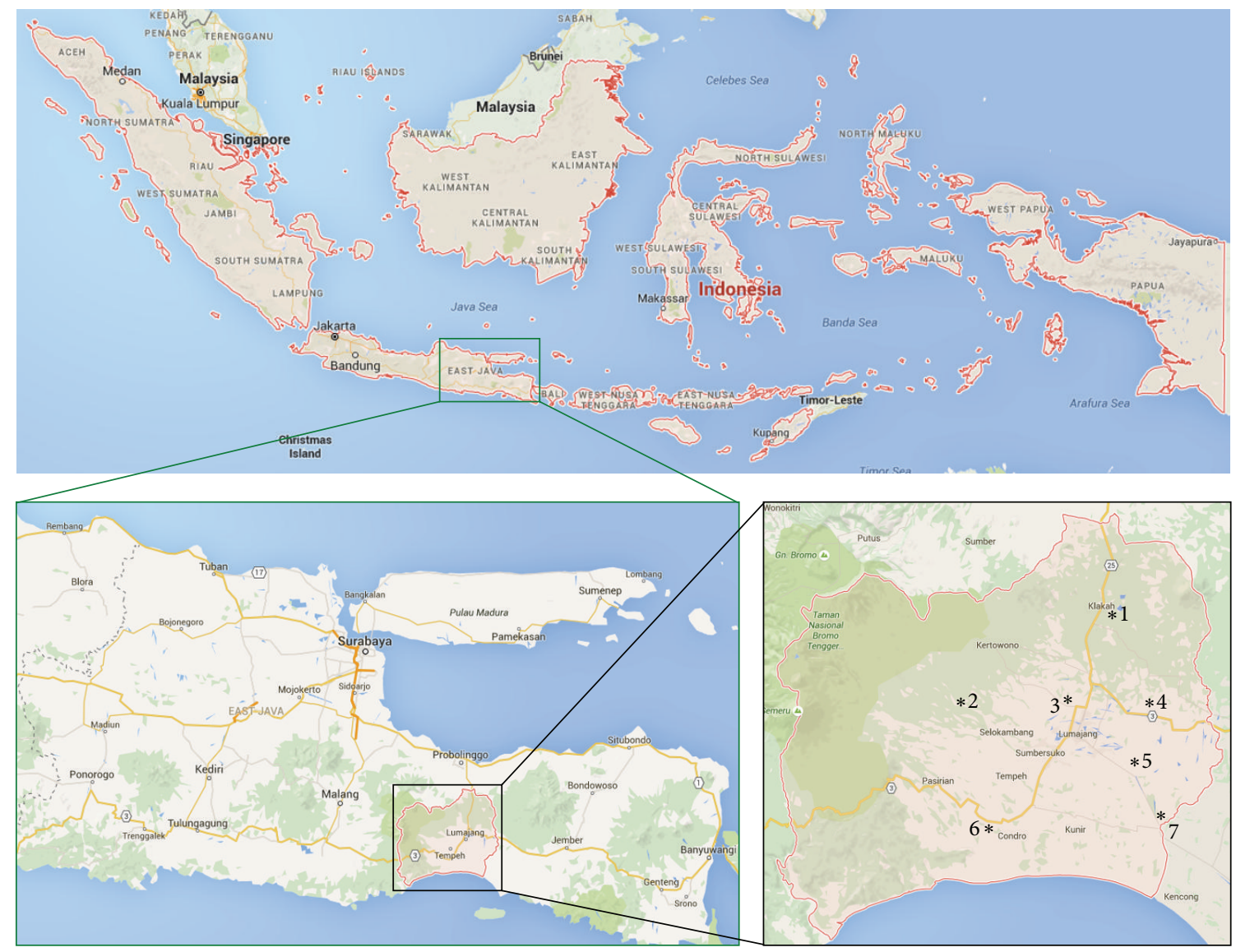

FIGURE 1: Location of banana’s sampling in Lumajang, East Java, Indonesia. Asterisk (*) refers to sampling spot area (modified from Google Maps) such as Kedung Jajang (1), Pasru Jambe (2), Sukodono (3), Randu Agung (4), Tekung (5), Tempeh (6), and Yosowilangun (7).

(Table 1). Interestingly, all isolates have $400 \mathrm{bp}$ fragments after PCR amplification using specific primer (FliC primer) for $R$. solanacearum (Figure 3(c)).

Isolation of bacteriophage that is able to infect bacterial wilt pathogen was done by exploring soil sample from Sukodono District and it was found that about two kinds of phages, namely, $\phi$ RSSKD1 and $\phi$ RSSKD2, were able to infect all bacterial isolates. However, phage-plaques morphology were different, which were turbid and clear plaques (Table 2, Figure 4). Furthermore, we also analyzed phages nucleic acid type by treating the purified phages genome with DNAse and RNAse. The result showed that all bacteriophages had DNA as their nucleic acid due to it sensitivity to DNAse but not to RNAse (Figure 4). 


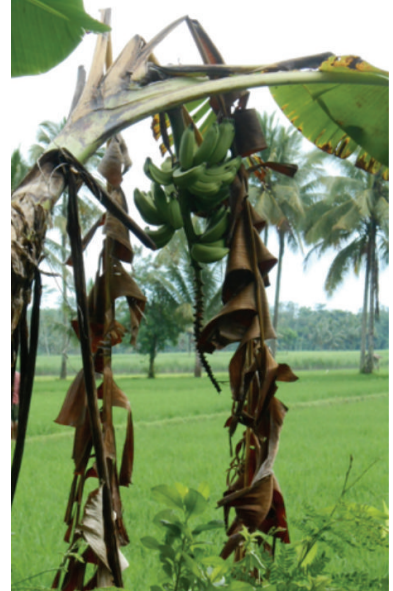

(a)

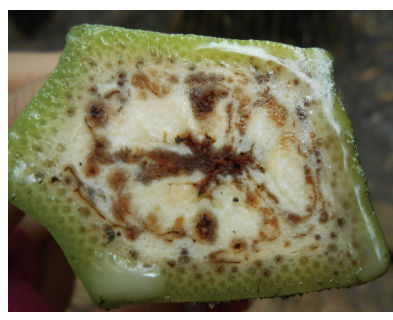

(c)

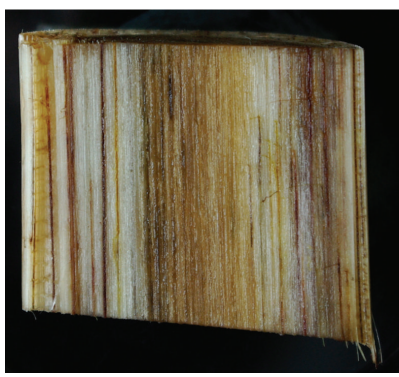

(e)

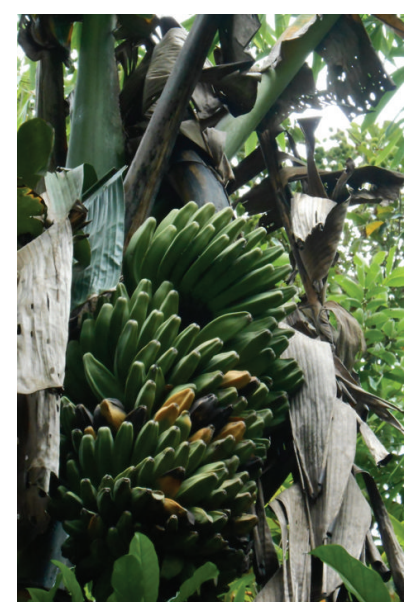

(b)

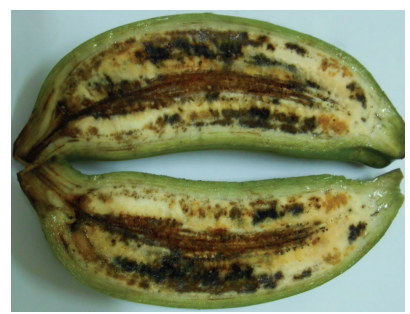

(d)

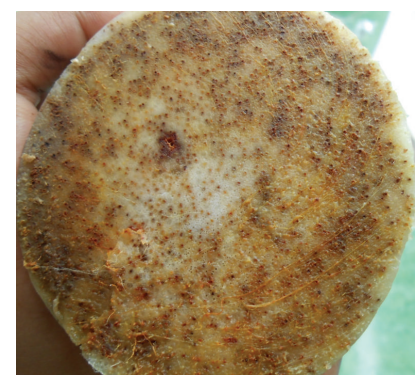

(f)

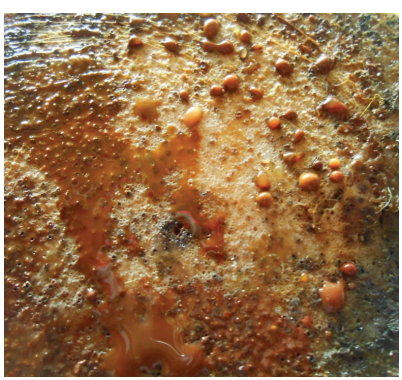

(g)

FIGURE 2: Wilt symptom on banana trees (a), bunches (b), fruits that are horizontally sliced (c), fruits that are vertically sliced (d), stems that are vertically sliced (e), stems that are horizontally sliced (f), and bacterial mass/ooze on the stem slice surface (g).

\section{Discussion}

Banana in Lumajang area that shows wilting, yellowing, and drying symptoms was particular symptom of bacterial wilt pathogen infection caused by $R$. solanacearum. The symptom becomes more contrasting while showing rotting in the center area of sliced fruit. This observation was similar to Nasir et al.s [4] during their observation on banana wilt disease in West Sumatra Province, Indonesia. More confirmation was also done by observing the morphological 


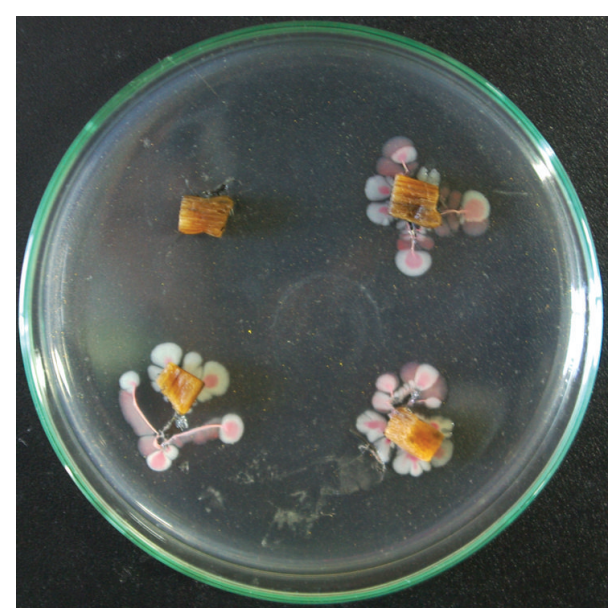

(a)

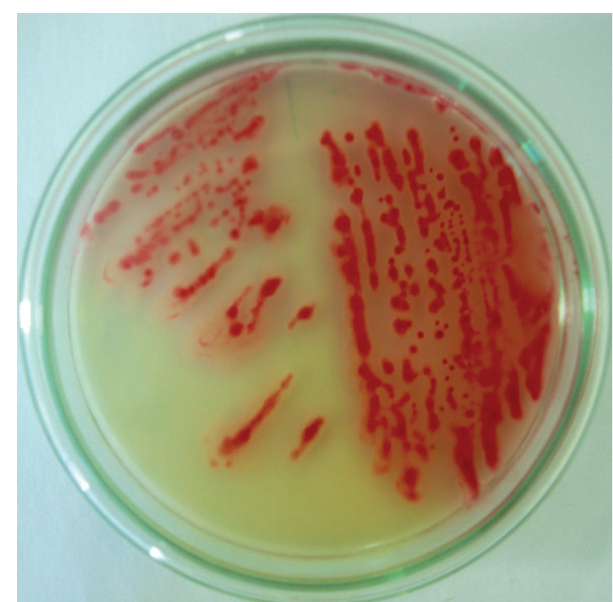

(b)

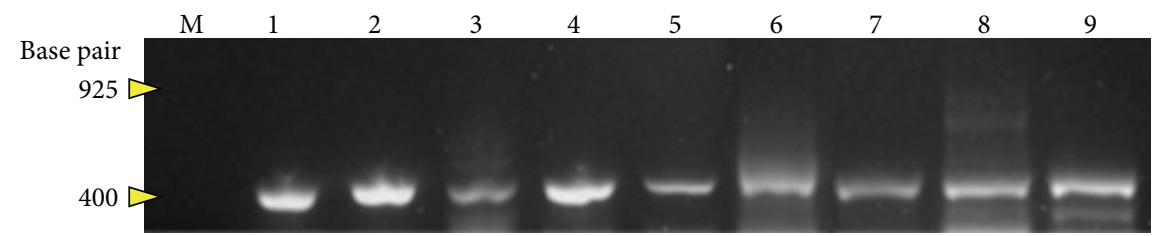

(c)

FIGURE 3: Morphological colonies of bacterial wilt pathogen grew around infected stem (a) and after purification of colony on CPG containing $0.01 \%$ TZC (b) which was detected by PCR using FliC primer (c). Lane M: $\lambda /$ StyI; Lanes 2-9 were based on isolate from Sukodono, Pasrujambe, Tempeh 1, Kedung Jajang, Tekung, Yosowilangun, Tempeh 2, Randu Agung 1, and Randu Agung 2, respectively.

TABLE 2: Host range of bacteriophage against $R$. solanacearum and its plaque morphology.

\begin{tabular}{lccc}
\hline \multirow{2}{*}{ Isolate codes } & Sensitivity $^{\text {a }}$ & \multicolumn{2}{c}{ Plaque morphology by phages } \\
& & $\phi$ RSSKD1 & $\phi$ RSSKD2 \\
\hline TP1 & + & Turbid & Turbid \\
TP2 & + & Turbid & Turbid \\
RA1 & + & Clear & Clear \\
RA2 & + & Clear & Clear \\
PJ1 & + & Clear & Clear \\
KJ2 & + & Clear & Clear \\
Yoso & + & Clear & Clear \\
TKG & + & Clear & Clear \\
SKD & + & Clear & Clear \\
\hline
\end{tabular}

${ }^{a}$ Results from five independent replications.

colonies of the causative agent and showed that all isolates had similar morphological colonies as described by Fegan and Prior [19]. Moreover, Liestiany et al. [20] described that the colony of $R$. solanacearum is fluidal and viscous and has irregular colony edge. Using PCR technique, all isolates can be determined using specific pair-primer such as FliC, which was designated to detect the presence of specific flagellin gene fragment on $R$. solanacearum species [17]. The FliC primer was widely used by some researchers to detect and identify R. solanacearum because it is highly specific and sensitive on PCR-based detection system as done by Huang et al. [21] who detected R. solanacearum from soil and Kubota et al. [22] who detected R. solanacearum isolated from banana.

On the other hand, we also isolated two bacteriophages, $\phi$ RSSKD1 and $\phi$ RSSKD2, from Sukodono soil. Both phages have similar ability to infect all bacterial isolates but differ in size of plaque. There were two types of bacterial host isolates related to plaque morphology; two isolates were given turbid plaques, while the remained seven isolates were given clear plaques. Interestingly, we obtained wide-host bacteriophages that are able to infect all isolated bacterial hosts. Fujiwara et al. [12] demonstrated that all different phages $\phi \mathrm{RSA} 1, \phi \mathrm{RSB} 1$, and $\phi$ RSL1 were able to infect $R$. solanacearum but with different host range. Askora et al. [23] also found two types of phages that have different host. Not all of these phages are able to infect all bacterial strains. We suggested that all isolates are the same strain even though it was isolated from different districts and banana cultivars. This suggestion is similar to Clokie et al.s [24] who demonstrated that plaques appearances may be affected by phages life cycle, phages host, and phage type. Both phage types have the same nucleic acid type, that is, DNA, due to the sensititivity to DNAse. Counis and Torriglia [25] suggested that nucleic acid type will be DNA if sensitive to DNAse but not to RNAse. Thus, we conclude that all isolates of bacterial wilt pathogen are $R$. solanacearum and both phages $\phi$ RSSKD1 and $\phi$ RSSKD 2 are phages with DNA as their nucleic acid.

Identification and determination of the causative agent of the disease is the critical step in the effort to determine appropriate control strategies [26]. There are many tactics 


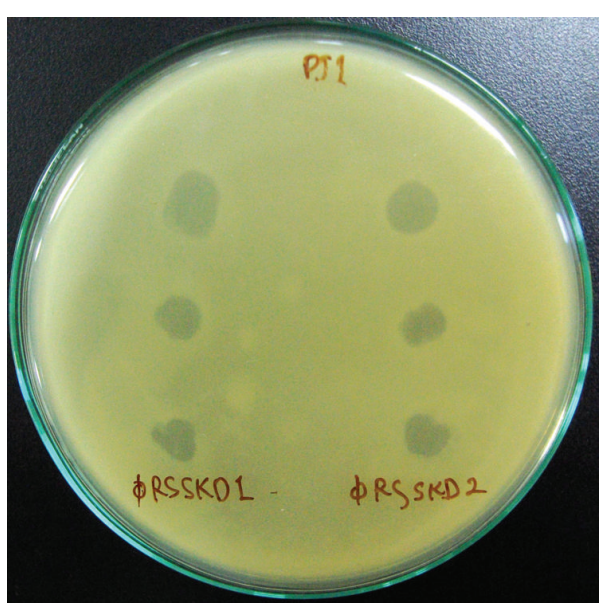

(a)

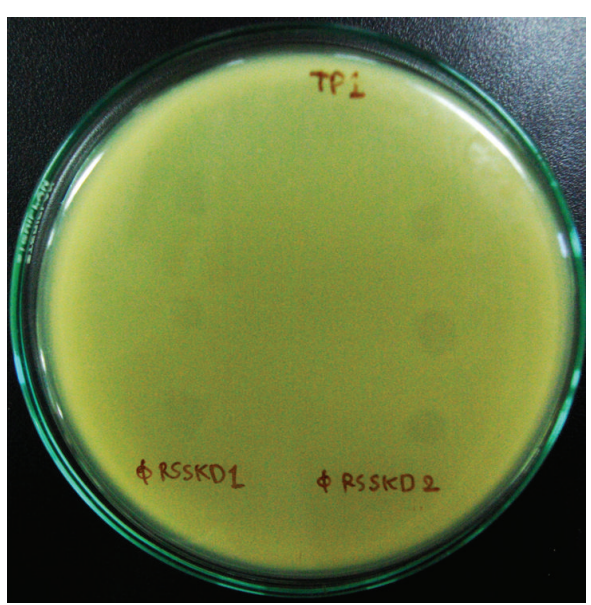

(b)

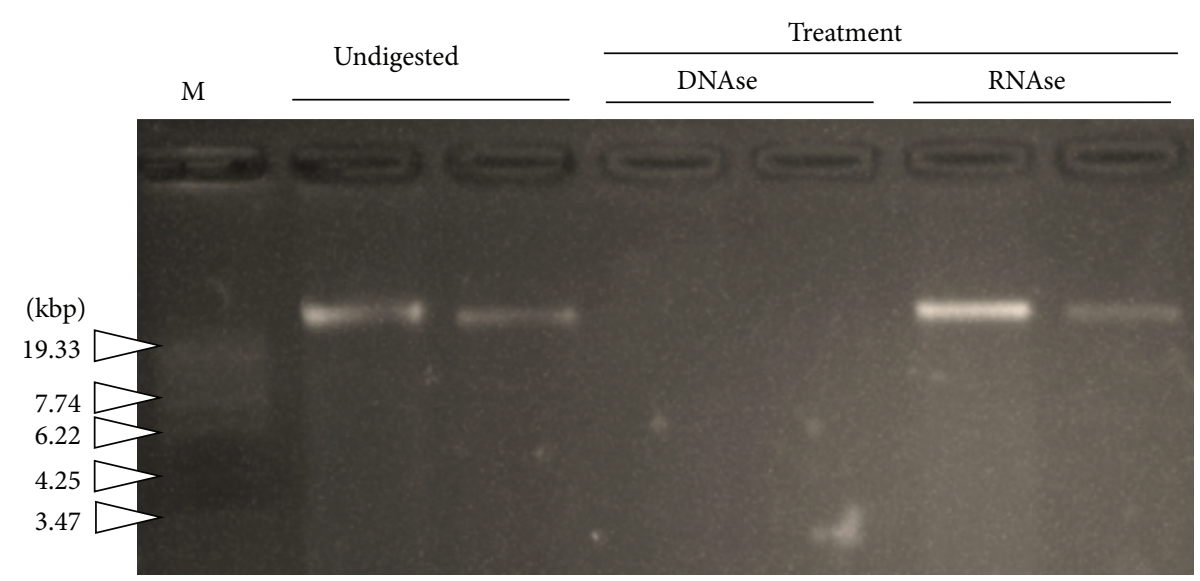

(c)

FIGURE 4: Spot assay on CPG medium showing different plaque morphologies which were clear (a) and turbid (b) plaques. Phage genome profiles which were treated/digested by two nucleases, DNAse and RNAse (c).

to control the disease, particularly plant disease caused by phytopathogenic bacteria such as the use of biological control agents. Utilization of bacteriophage as biocontrol agent against phytopathogenic bacteria has been studied and investigated both at laboratory scale and on a field scale which exposed the strategies in utilizing bacteriophage related to the environment condition. Fujiwara et al. [12] utilized bacteriophage like $\phi$ RSA1 to treat soil borne pathogens, $R$. solanacearum, with high efficacy without using special formulation to phage. They directly poured or sprayed phage suspension into soil which was infested by bacterial host. This procedure implies that environmental conditions in the soil do not extremely affect stability of bacteriophage compared to the condition on soil surface or plant part above soil surface. In contrast, Iriarte et al. [27] demonstrated the use of bacteriophages $\phi$ XV3-16 and $\phi \mathrm{Xacm} 2004-16$ in formulated way to combat Xanthomonas that infects tomato leaves. This indicates that the phage stability and infectivity is influenced by the location of pathogen associated with the affected plant parts, especially those directly exposed to extreme environmental factors. The use of this formula aims to protect bacteriophage from damage due to extreme environmental conditions such as UV and high temperature [28] resulting in loss of phage infectivity.

\section{Competing Interests}

The authors declare that there is no conflict of interests regarding the publication of this paper.

\section{References}

[1] P. E. Prahardini, Yuniarti, and A. Krismawati, "Characterization of superior banana of mas kirana and agung semeru varieties in lumajang district," Buletin Plasma Nutfah, vol. 16, no. 2, pp. 126133,2010

[2] J. D. Van Elsas, P. Kastelein, P. M. De Vries, and L. S. Van Overbeek, "Effects of ecological factors on the survival and physiology of Ralstonia solanacearum bv. 2 in irrigation water," Canadian Journal of Microbiology, vol. 47, no. 9, pp. 842-854, 2001.

[3] M. F. C. Ilagan, M. T. M. Perez, and A. K. Raymundo, "Direct detection of race 2 Ralstonia solanacearum (Smith) yabuuchi 
in banana fruit stalk using polymerase chain reaction," The Philippine Agricultural Scientist, vol. 93, no. 3, pp. 307-316, 2010.

[4] N. Nasir, Jumjunidang, and Riska, "Distribution of Fusarium wilt and bacterial wilt on germplasm location and field school of integrated pest management in West Sumatra," Jurnal Horticultura, vol. 15, no. 3, pp. 215-222, 2005.

[5] A. Kelman, "The relationship of pathogenicity in Pseudomonas solanacearum to colony appearance on a tetrazolium medium," Phytopathology, vol. 44, pp. 693-695, 1954.

[6] J. G. Elphinstone, "The current bacterial wilt situation: a global overview," in Bacterial Wilt Disease and the Ralstonia solanacearum Species Complex, C. Allen, P. Prior, and A. C. Hayward, Eds., pp. 9-28, American Phytopathological Society Press, St. Paul, Minn, USA, 2005.

[7] D. Ahimelash, S. T. Alemu, T. Addis, F. L. Turyagyenda, and G. Blomme, "Banana Xanthomonas wilt in Ethiopia: occurrence and insect vector transmission," African Crop Science Journal, vol. 16, no. 1, pp. 75-78, 2010.

[8] S. E. Seal, L. A. Jackson, J. P. W. Young, and M. J. Daniels, “Differentiation of Pseudomonas solanacearum, Pseudomonas syzygii, Pseudomonas pickettii and the blood disease bacterium by partial $16 \mathrm{~S}$ rRNA sequencing-construction of oligonucleotide primers for sensitive detection by polymerase chain reaction,", Journal of General Microbiology, vol. 139, no. 7, pp. 1587-1594, 1993.

[9] S. Hagens and M. J. Loessner, "Application of bacteriophages for detection and control of foodborne pathogens," Applied Microbiology and Biotechnology, vol. 76, no. 3, pp. 513-519, 2007.

[10] Yuliar, Y. A. Nion, and K. Toyota, "Recent trends in control methods for bacterial wilt diseases caused by Ralstonia solanacearum," Microbes and Environments, vol. 30, no. 1, pp. 1-11, 2015.

[11] H. S. Addy, A. Askora, T. Kawasaki, M. Fujie, and T. Yamada, "Utilization of filamentous phage $\varphi$ RSM3 to control bacterial wilt caused by Ralstonia solanacearum," Plant Disease, vol. 96, no. 8, pp. 1204-1209, 2012.

[12] A. Fujiwara, M. Fujisawa, R. Hamasaki, T. Kawasaki, M. Fujie, and T. Yamada, "Biocontrol of Ralstonia solanacearum by treatment with lytic bacteriophages," Applied and Environmental Microbiology, vol. 77, no. 12, pp. 4155-4162, 2011.

[13] A. A. Ahmad, A. Askora, T. Kawasaki, F. Makoto, and T. Yamada, "The filamentous phage XacF1 causes loss of virulence in Xanthomonas axonopodis pv. Citri, the causative agent of citrus canker disease," Frontier Microbiology, vol. 5, no. 321, pp. 1-14, 2014.

[14] B. Balogh, J. B. Jones, F. B. Iriarte, and M. T. Momol, "Phage therapy for plant disease control," Current Pharmaceutical Biotechnology, vol. 11, no. 1, pp. 48-57, 2010.

[15] N. R. Dhany, H. S. Addy, and W. S. Wahyuni, "The use of a bacteriophage for detector kit of bacterial blight pathogen on soybean," Jurnal Fitopatologi Indonesia, vol. 9, no. 4, pp. 116-122, 2013.

[16] J. Sambrook, P. Maccallum, and D. Russel, Molecular Cloning: A Laboratory Manual, Cold Springs Harbour Press, New York, NY, USA, 3rd edition, 2001.

[17] J. Schönfeld, H. Heuer, J. D. van Elsas, and K. Smalla, "Specific and sensitive detection of Ralstonia solanacearum in soil on the Basis of PCR amplification of fliC fragments," Applied and Environmental Microbiology, vol. 69, no. 12, pp. 7248-7256, 2003.

[18] G. Susianto, M. M. Farid, N. R. Dhany, and H. S. Addy, "Host range for bacteriophages that infect bacterial blight pathogen on soybean," Procedia Environmental Sciences, vol. 20, pp. 760 766, 2014.

[19] M. Fegan and P. Prior, "Diverse members of the Ralstonia solanacearum species complex cause bacterial wilts of banana," Australasian Plant Pathology, vol. 35, no. 2, pp. 93-101, 2006.

[20] E. Liestiany, E. N. Fikri, and E. Susilowati, "Kemampuan Pseudomonas kelompok fluorescens dari Kabupaten Tabalong menekan pertumbuhan Ralstonia solanacearum secara in vitro," Agripeat, vol. 13, no. 1, pp. 8-15, 2012.

[21] J. Huang, J. Wu, C. Li, C. Xiao, and G. Wang, "Specific and sensitive detection of Ralstonia solanacearum in soil with quantitative, real-time PCR assays," Journal of Applied Microbiology, vol. 107, no. 5, pp. 1729-1739, 2009.

[22] R. Kubota, B. G. Vine, A. M. Alvarez, and D. M. Jenkins, “Detection of Ralstonia solanacearum by loop-mediated isothermal amplification," Phytopathology, vol. 98, no. 9, pp. 1045-1051, 2008.

[23] A. Askora, T. Kawasaki, S. Usami, M. Fujie, and T. Yamada, "Host recognition and integration of filamentous phage $\phi$ RSM in the phytopathogen, Ralstonia solanacearum," Virology, vol. 384, no. 1, pp. 69-76, 2009.

[24] M. R. J. Clokie, A. D. Millard, A. V. Letarov, and S. Heaphy, "Phage in nature," Bacteriophage, vol. 1, no. 1, pp. 31-45, 2011.

[25] M.-F. Counis and A. Torriglia, "Acid DNases and their interest among apoptotic endonucleases," Biochimie, vol. 88, no. 12, pp. 1851-1858, 2006.

[26] R. A. Frampton, A. R. Pitman, and P. C. Fineran, "Advances in bacteriophage-mediated control of plant pathogens," International Journal of Microbiology, vol. 2012, Article ID 326452, 11 pages, 2012.

[27] F. B. Iriarte, B. Balogh, M. T. Momol, L. M. Smith, M. Wilson, and J. B. Jones, "Factors affecting survival of bacteriophage on tomato leaf surfaces," Applied and Environmental Microbiology, vol. 73, no. 6, pp. 1704-1711, 2007.

[28] J. B. Jones, G. E. Vallad, F. B. Iriarte et al., "Considerations for using bacteriophages for plant disease control," Bacteriophage, vol. 2, no. 4, pp. 208-214, 2012. 


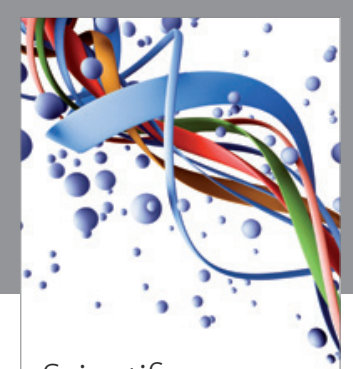

Scientifica
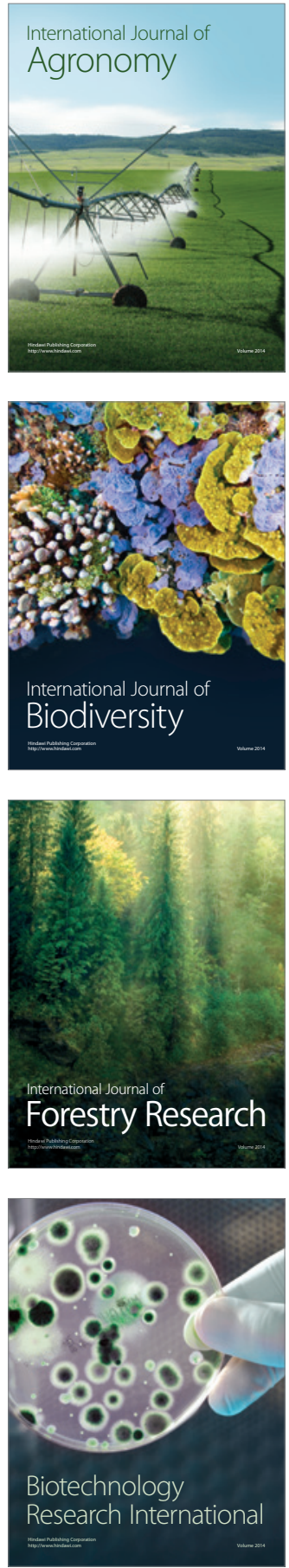
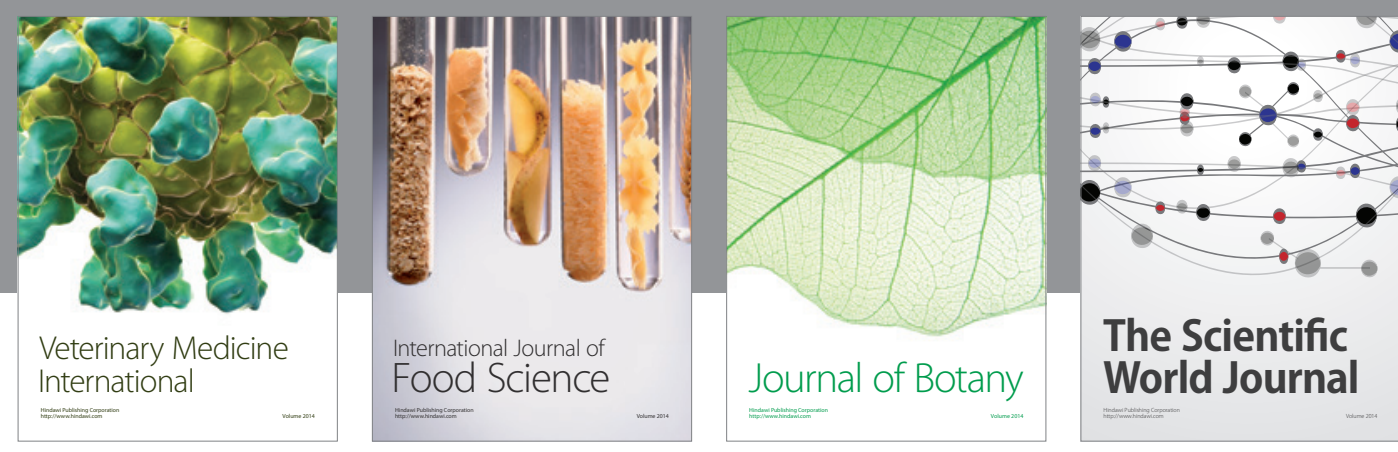

The Scientific

\section{World Journal}

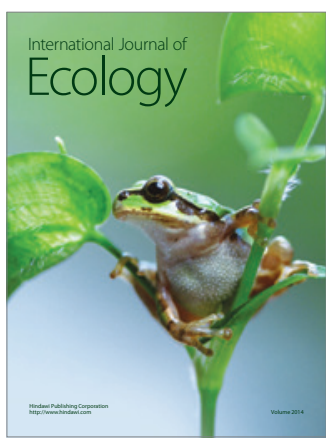

\section{Hindawi}

Submit your manuscripts at

http://www.hindawi.com
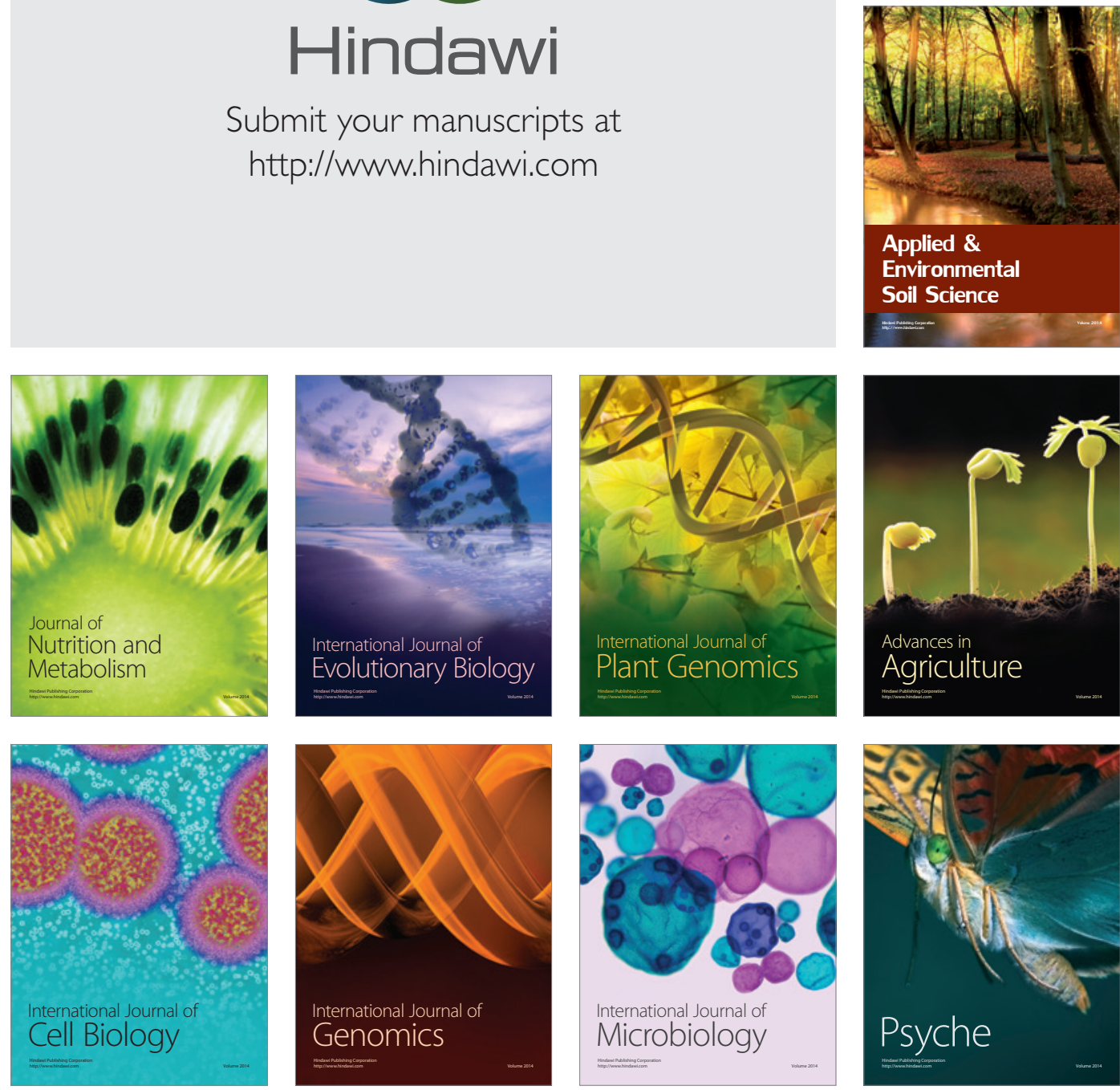
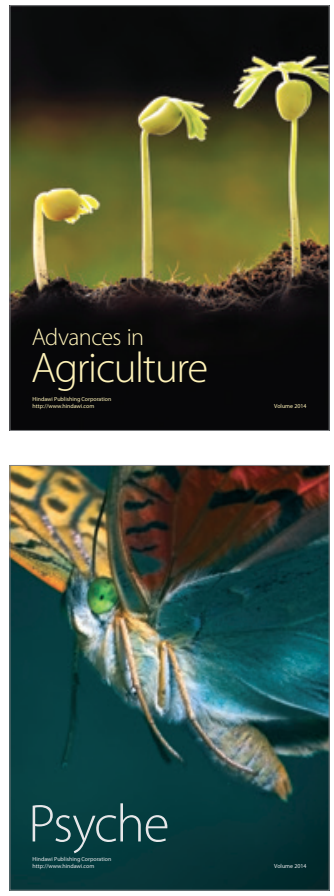